\title{
A COMPARISON BETWEEN THIN-FILM TRANSISTORS DEPOSITED BY HOT-WIRE CHEMICAL VAPOR DEPOSITION AND PECVD
}

\author{
Meysam Zarchi*, Shahrokh Ahangarani \\ Advanced Materials \& Renewable Energies Department, Iranjan rearch \\ Organization for Science and Technology, Tehrav Iran \\ Abstract \\ Received 20.08.2014 \\ Accepted 30.09.2014
}

The effect of new growth techniques on 1 mobility nd stability of amorphous silicon (a-Si:H) thin film transistors (TFTs) $\mathrm{h}$ /s been studied. It was suggested that the key parameter controlling the field-effect mo ility and s ability is the intrinsic stress in the a-Si:H layer. Amorphous and microcrys lline silycon films were deposited by radiofrequency plasma enhanced chen al vapor urposition (RF-PECVD) and hot-wire chemical vapor deposition (HW-CVD) at ${ }^{\circ} \mathrm{C}$ and $25^{\circ} \mathrm{C}$. Structural properties of these films were measured by Rama Spectroscopy. Electronic properties were measured by dark conductiy $1 \mathrm{y}, \mathrm{O}$, and potoconductivity, $\sigma_{\mathrm{ph}}$. For amorphous silicon films deposited by RF-PFC $\mathrm{Cn}$ on notosensitivity's of $>10^{5}$ were obtained at both $100^{\circ} \mathrm{C}$ and $25^{\circ} \mathrm{C}$. For a orphous silicon films deposited by HW-CVD, a photosensitivity of $0^{5}$ was 0 aained at $100{ }^{\circ} \mathrm{C}$. Microcrystalline silicon films deposited by HW-CVD $95 \%$ hydrogen dilution show $\sigma_{\mathrm{ph}} \sim 10^{-4} \Omega^{-1} \mathrm{~cm}^{-1}$, while maintaining a hotosensitiv $\int$ of $\sim 10^{2}$ at both $100{ }^{\circ} \mathrm{C}$ and $25{ }^{\circ} \mathrm{C}$. Microcrystalline silicon films th 2 rerge crystalline fraction $(>50 \%)$ can be deposited by HW-CVD all the way down to om tomperature.

Keyw rd: , pin Filin ransistors, PECVD, Deposited, Silicon Films, Stress

\section{Introduc ion}

Amorphous, flicon (a-Si:H) thin film transistors (TFT), commonly deposited by plasma enhanced chemical vapor deposition (PECVD) at $13.56 \mathrm{MHz}$, are widely used as pixelswitching devices in large area electronics. The low field-effect mobility $\left(<1 \mathrm{~cm}^{2}=\mathrm{V} \mathrm{s}\right)$ and the limited stability under gate bias stress, due to defect creation in the a-Si:H, complicates the utilization in applications where high performance is demanded, such as OLED displays and column/row-addressing circuitry. While the low mobility is attributed to the inherent condition of a-Si:H, the microscopic specifics of the defectcreation mechanism (Staebler-Wronski effect) are still elusive.

*Corresponding autor: M. Zarchi, sky_man1983@yahoo.com 
TFTs incorporating PECVD a-Si:H with high compressive stress exhibited a poor stability [1]. This was explained with a high fraction of short (compressed) Si-Si bonds, of which the energy levels are located in the valence-band tail, which tend to break under charge accumulation, thus forming dangling-bond defects. This process is thermally activated with an exponential distribution of barrier heights.

Since 'device-quality' a-Si:H usually has high compressive stress, combining a high field-effect mobility with a high TFT stability seems to be contradictious. Therefore, other deposition techniques, such as very-high frequency (VYIT) C CVD [2] and hot-wire (HW) CVD [3] have been used for TFT deposition. It $c$ ld be sho vn that TFTs with a high stability, maintaining a high mobility, are feasib, [4]. Ve now present a comprehensive study of the stability and mobility of $\mathrm{AF}$ and ho vire TFTs.

\section{Experimental Procedures}

For HW deposition, a single tungsten filame it of $0.5 \mathrm{Am}$ diameter and approximately $7 \mathrm{~cm}$ total length was placed $5 \mathrm{~cm}$ fron the $\mathrm{bstrate}$ and was resistively heated with a DC power supply.

The filament temperature was $\mathrm{m}$ asured with an optical pyrometer (Tfil $\sim 2500{ }^{\circ} \mathrm{C}$ ) and the pressure was kept con ant at 20 TTorr. For the RF deposition, the inter-electrode distance was $3 \mathrm{~cm}$, the densis ${ }^{2}$ power used was $50 \mathrm{~mW} / \mathrm{cm}^{2}$ (in all experiments, but at the room the diture depositions where RF power was $100 \mathrm{~mW} / \mathrm{cm}^{2}$, whereas the pressure ws $\left.100 \mathrm{mTorr}\right)$. For both the HW and RF depositions, the sum of gas fluyes as kep at around $10 \mathrm{~cm}^{3} / \mathrm{min}$, except for the higher dilutions where it was neces o v to increas the flux so that the SiH4 flux was not less than $0.5 \mathrm{~cm}^{3} / \mathrm{min}$, which ws the ower rimit for the silane mass flow controller. Films were deposited on $\mathrm{Cg}$, ing 7059 sos and polyethylene terephthalate (PET) [7]. The PET was covered o a $90 \mathrm{~nm}$ thick SiNx passivation layer. Raman spectra were measured in the oakscattern geometry using a Raman microprobe. The power of the incident beam vas selow $50 \mathrm{~mW}$ to avoid thermally induced crystallization [8-10].

\section{Result} substrate.

ble 1 sum narizes the measured properties of selected films deposited on

Table 1. Properties of films deposited on substrate.

\begin{tabular}{|c|c|c|c|c|c|c|c|c|c|c|c|c|}
\hline CVD & \multicolumn{6}{|c|}{ RF-PECVD (a-Si:H) } & \multicolumn{6}{|c|}{ HW (a-Si:H) } \\
\hline Temp & & $25^{\circ} \mathrm{C}$ & & & $100^{\circ} \mathrm{C}$ & & & $25^{\circ} \mathrm{C}$ & & & $100^{\circ} \mathrm{C}$ & \\
\hline Sample & S1493 & $\mathrm{S} 1518$ & S1489 & S1486 & S1520 & S1487 & S1515 & S1494 & S1519 & S1501 & S1488 & S1498 \\
\hline $\mathbf{H}_{2}(\%)$ & 98 & 99 & 99 & 96 & 98 & 98 & 80 & 80 & 90 & 60 & 60 & 90 \\
\hline $\begin{array}{c}\mathbf{d} \\
(\mu \mathrm{m})\end{array}$ & 0.1 & 0.3 & 0.1 & 0.1 & 0.3 & 0.1 & 0.3 & 0.1 & 0.3 & 1.0 & 0.1 & 0.1 \\
\hline $\begin{array}{c}\begin{array}{c}\boldsymbol{\sigma}_{\mathbf{d}} \\
\left(\Omega^{-1} \mathrm{~cm}^{-1}\right)\end{array} \\
\end{array}$ & $\begin{array}{l}1.9 \mathrm{x} \\
10^{-11}\end{array}$ & $\begin{array}{c}6.3 \times \\
10^{-9}\end{array}$ & $\begin{array}{c}1.1 \mathrm{x} \\
10^{-9}\end{array}$ & $\begin{array}{l}1.0 \mathrm{x} \\
10^{-10}\end{array}$ & $\begin{array}{l}3.8 x \\
10^{-6}\end{array}$ & $\begin{array}{l}1.4 \mathrm{x} \\
10^{-11}\end{array}$ & $\begin{array}{l}6.9 \mathrm{x} \\
10^{-10}\end{array}$ & $\begin{array}{l}3.8 \times \\
10^{-10}\end{array}$ & $\begin{array}{c}2.0 \times \\
10^{-7}\end{array}$ & $\begin{array}{l}2.4 \mathrm{x} \\
10^{-11}\end{array}$ & $\begin{array}{l}1.3 \mathrm{x} \\
10^{-10}\end{array}$ & $\begin{array}{c}2.5 \mathrm{x} \\
10^{-6}\end{array}$ \\
\hline $\begin{array}{c}\mathbf{E}_{\mathbf{a}} \\
(\mathrm{eV})\end{array}$ & 0.43 & 0.66 & 0.57 & 0.87 & 0.4 & 0.9 & 0.74 & 0.65 & 0.68 & 0.55 & 0.85 & 0.56 \\
\hline $\begin{array}{c}\boldsymbol{\sigma}_{\mathbf{p h}} \\
\left(\Omega^{-1} \mathrm{~cm}^{-1}\right)\end{array}$ & $\begin{array}{c}1.1 \mathrm{X} \\
10^{-7}\end{array}$ & $\begin{array}{c}3.5 \times \\
10^{-9}\end{array}$ & $\begin{array}{c}3.7 \mathrm{x} \\
10^{-6}\end{array}$ & $\begin{array}{c}5.0 \mathrm{x} \\
10^{-6}\end{array}$ & $\begin{array}{c}2.4 \mathrm{x} \\
10^{-8}\end{array}$ & $\begin{array}{c}7.6 \times \\
10^{-6}\end{array}$ & $\begin{array}{c}2.0 \mathrm{x} \\
10^{-7}\end{array}$ & $\begin{array}{c}2.9 \times \\
10^{-7}\end{array}$ & $\begin{array}{c}6.2 \times \\
10^{-8}\end{array}$ & $\begin{array}{c}3.4 \mathrm{x} \\
10^{-6}\end{array}$ & $\begin{array}{c}2.2 \mathrm{x} \\
10^{-5}\end{array}$ & $\begin{array}{l}1.5 \mathrm{x} \\
10^{-7}\end{array}$ \\
\hline
\end{tabular}


where: $\mathrm{d}$ - film thickness, $\sigma_{\mathrm{d}^{-}}$dark conductivity, $\Omega^{-1} \mathrm{~cm}^{-1}$ and $\sigma_{\mathrm{ph}}$-photoconductivity, $\Omega^{-1}$ $\mathrm{cm}^{-1}$

The Raman spectra of films deposited by RF-PECVD on PET (Fig. 1a and Fig. 1b) show the dependence of the crystalline fraction on film thickness of samples deposited at substrate temperatures of $100^{\circ} \mathrm{C}$ and $25^{\circ} \mathrm{C}$.

When the film thickness increases from 100 to $300 \mathrm{~nm}$, the crystalline fraction increases from 16 to $40 \%$ for the film deposited at $\mathrm{T}_{\text {sub }}=25^{\circ} \mathrm{C}$ and $99 \%$ tion, and from 12 to $55 \%$ for the film deposited at $\mathrm{T}_{\text {sub }}=100{ }^{\circ} \mathrm{C}$ and $98 \% \mathrm{H}_{2}$ dilut $\mathrm{n}$. The crystalline fractions of the $300 \mathrm{~nm}$ RF films on PET approa those of the corresponding films deposited on glass, i.e. $42 \%$ for the $25^{\circ} \mathrm{C}$ and $58 \%$ vr t $/ \mathrm{e} 100^{\circ} \mathrm{C}$ sample. The same effect can be observed in the case of the K filp depos, ed at $25^{\circ} \mathrm{C}$ on PET using 90\% hydrogen dilution (Fig. 1c).

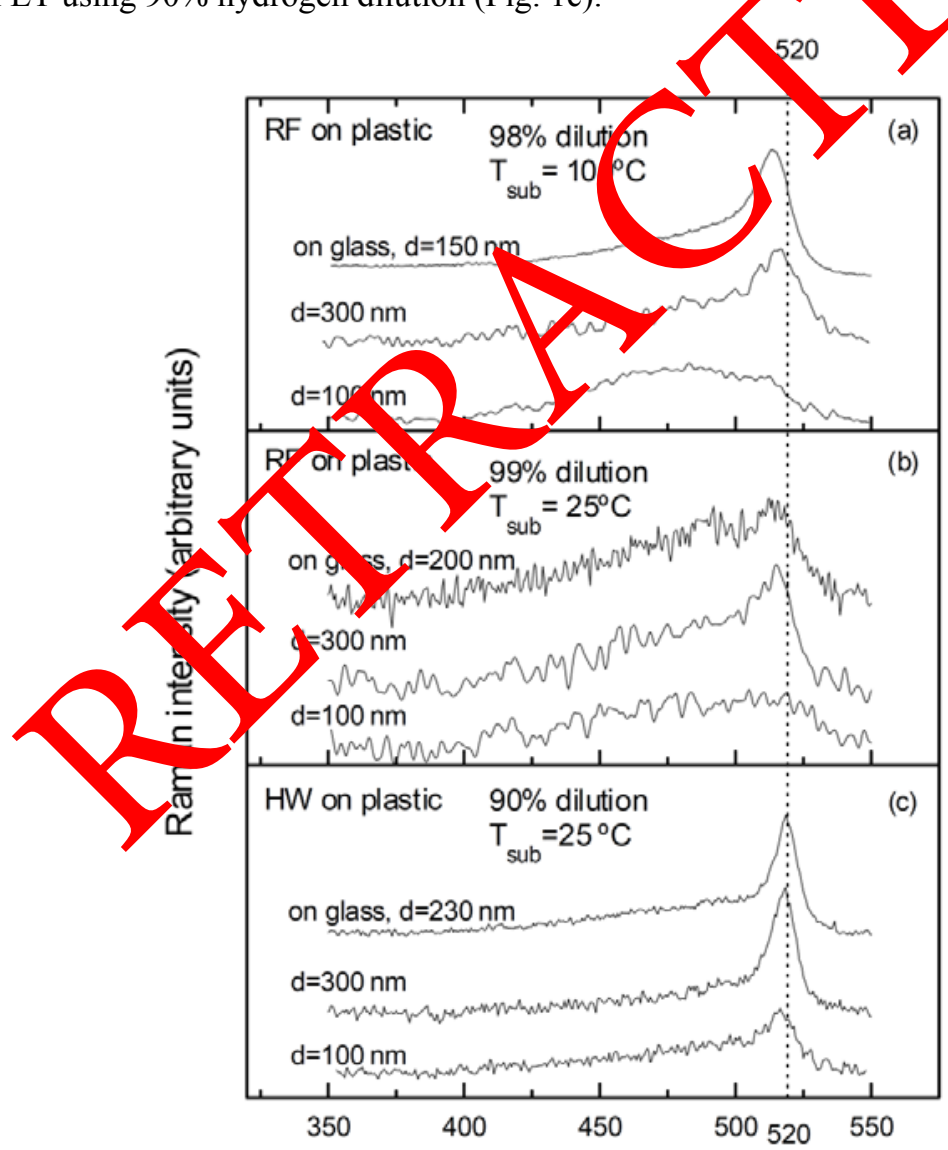

Raman shift, $\Delta \omega\left(\mathrm{cm}^{-1}\right)$

Fig. 1. Raman spectra for (a) RF on PET deposited using $98 \%$ hydrogen dilution at $T_{\text {sub }}=100{ }^{\circ} \mathrm{C}$; (b) RF on PET using 99\% hydrogen dilution at $T_{\text {sub }}=25^{\circ} \mathrm{C}$; (c) $\mathrm{HW}$ on PET using $90 \%$ hydrogen dilution at $T_{\text {sub }}=25^{\circ} \mathrm{C}$. 
The crystalline fraction increases from $24 \%$ for a $100 \mathrm{~nm}$ film to $62 \%$ for a 300 $\mathrm{nm}$ film, closely matching the $57 \%$ value for a $230 \mathrm{~nm}$ film deposited on substrate using the same deposition conditions.

The Raman spectra in Fig.2 illustrate the amorphous to microcrystalline transition as a result of increasing the hydrogen dilution of silane in films deposited on PET at $\mathrm{T}_{\text {sub }}=25^{\circ} \mathrm{C}$ by RF (Fig. 2a) and by HW (Fig. 2b). All samples were $300 \mathrm{~nm}$ thick, except the $95 \% \mathrm{H}_{2}$ diluted film by $\mathrm{HW}$ which was $100 \mathrm{~nm}$ thick.

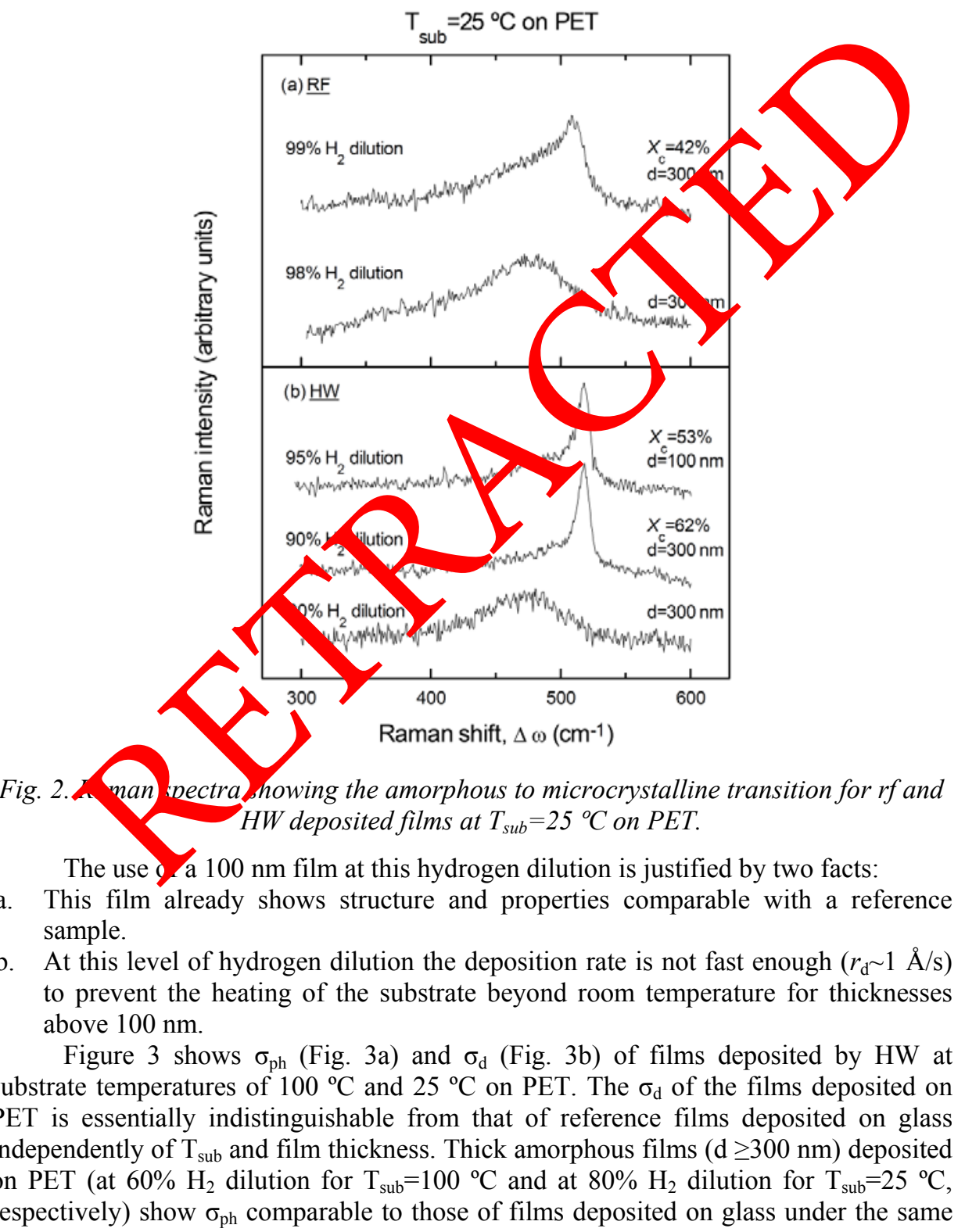


conditions and with the same thickness. However, when deposited on PET, the electronic properties of these films show a very strong dependence on film thickness resulting in a decrease of $\sigma_{\mathrm{ph}}$ of 1-2 orders of level for a decrease of film thickness from $300 \mathrm{~nm}$ to $100 \mathrm{~nm}$.

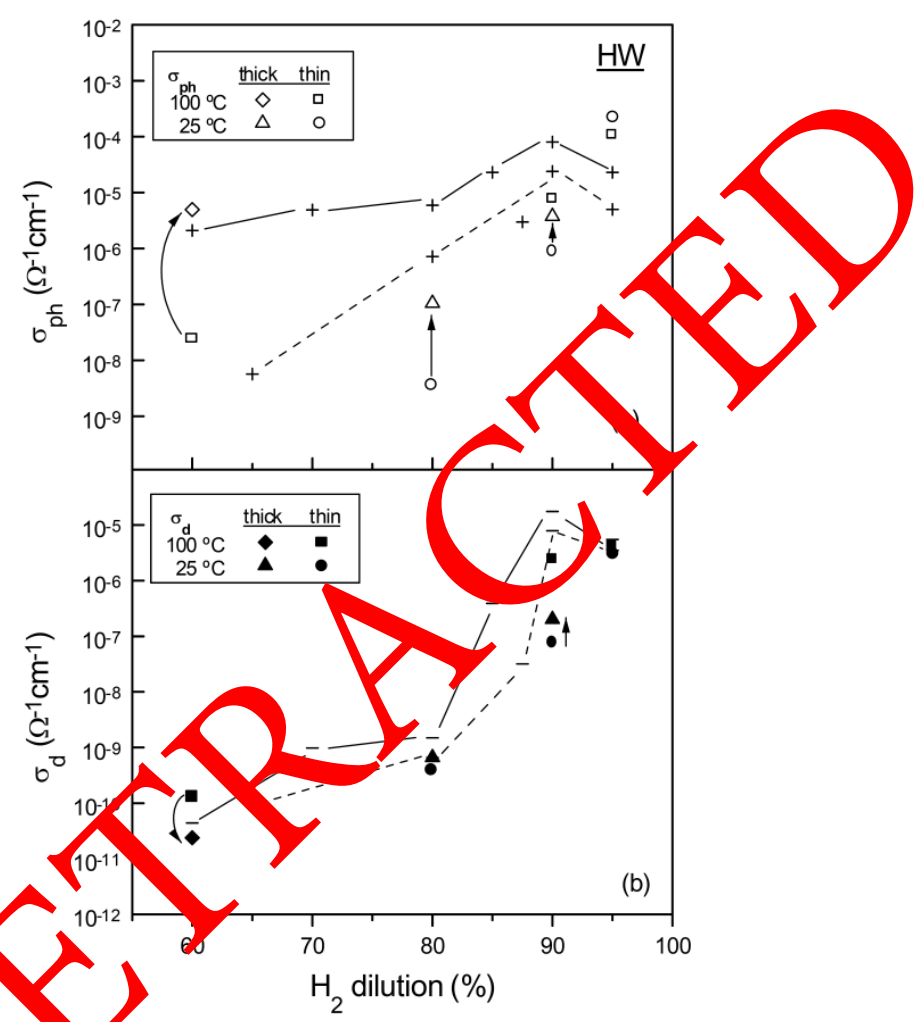

E. 3. (4) Photo onductivity (at a carrier generation rate of $10^{21} \mathrm{~cm}^{-3} \mathrm{~s}^{-1}$ ) and (b) dark co aucturuy of $\mathrm{HW}$ deposited films as a function of hydrogen dilution. The dark (-) and pho onductivity (+) of films grown on substrates at $T_{\text {sub }}=100{ }^{\circ} \mathrm{C}$ (continuous line) and at $3_{\text {sub }}=25^{\circ} \mathrm{C}$ (dashed line) are shown for comparison. The arrows point out the increase in $\sigma_{p h}$ and $\sigma_{d}$ when the thickness of the film is increased from $0.1 \mu \mathrm{m}$ (thin) to $0.3 \mu \mathrm{m}$ (thick).

At $90 \%$ hydrogen dilution and $\mathrm{T}_{\text {sub }}=25{ }^{\circ} \mathrm{C}$, od shows transport properties intermediate between typical amorphous and typical microcrystalline values $\left(\sim 10^{-7} \Omega^{-1} \mathrm{~cm}^{-1}\right) . \sigma_{\mathrm{ph}}$ experiences a fourfold increase when film thickness increases from 100 to $300 \mathrm{~nm}$ (from $9.1 \times 10^{-7} \Omega-1 \mathrm{~cm}^{-1}$ to $3.7 \times 10^{-6} \Omega-1 \mathrm{~cm}^{-1}$ ). At $\mathrm{T}_{\text {sub }}=100{ }^{\circ} \mathrm{C}$ the $100 \mathrm{~nm}$ film has $\sigma_{\mathrm{ph}}\left(7.6 \times 10^{-6} \Omega^{-1} \mathrm{~cm}^{-1}\right)$, one order of magnitude beneath the reference $500 \mathrm{~nm}$ films on glass. On the other hand, at higher values of hydrogen dilution (95\%), the thin $(100 \mathrm{~nm})$ films deposited on PET have higher $\sigma_{\mathrm{ph}}$ than the thick $(500 \mathrm{~nm})$ reference films on substrate without a corresponding increase in $\sigma_{\mathrm{d}}$. 


\section{Discussion}

a-Si:H and $\mu_{\mathrm{c}}-\mathrm{Si}: \mathrm{H}$ films were deposited on PET at $\mathrm{T}_{\text {sub }}=25^{\circ} \mathrm{C}$ and $\mathrm{T}_{\text {sub }}=100{ }^{\circ} \mathrm{C}$ with good adhesion and mechanical stability. Small deformations applied to the substrate within its elastic limit cause no apparent damage to the films.

Both Raman and conductivity data indicate a strong thicknescmenendence of structure and optoelectronic properties in all HW films except i, those here high hydrogen dilution (95\%) was used. This dependence, already or ved in a norphous HW films on glass deposited at the same temperatures (a) Amough ob orved for $\mathrm{Tsub} \geq 220^{\circ} \mathrm{C}[5]$ ) and in microcrystalline $\mathrm{HW}$ films (thou h in yuch th ner films, in the $10 \mathrm{~nm}$ range) on substrate, becomes more pronounged in cas of deposition on PET. RF amorphous films show no thickness dep dence on the properties while microcrystalline films again show that effect, in $\mathrm{p}$ rtio $\mathrm{ar}$ films eposited at the onset of the amorphous to microcrystalline transition This is articularly obvious for the $\mathrm{T}_{\text {sub }}=100 \quad{ }^{\circ} \mathrm{C}$ and $98 \% \quad \mathrm{H}_{2}$ dilution film Qee Table 1) where $\sigma_{\mathrm{d}} \sim 10^{-11} \Omega^{-1} \mathrm{~cm}^{-1}$ for the $100 \mathrm{~nm}$ film, i dicating conduction through a dominant amorphous tissue, while $\sigma_{\mathrm{d}} \sim 5.10^{-6} \Omega^{-1} \mathrm{~cm}^{-1} \mathrm{ft}$ the $300 \mathrm{~m}$ film is more characteristic of microcrystalline transport. This thic'sness depunuce may have implications in the design of devices incorporating these film

The use of hydrogen dilution, bot in $\mathrm{k}, \mathrm{and} \mathrm{HW}$, allows the deposition of films on PET with improved opto eted onic pi onerties that are comparable to those deposited on substrate using the ne denosition conditions, provided that the thickness dependence is taken no aco unt. Of particular importance are the microcrystalline films by HW depos d with 95 nydrogen dilution where the large supply of atomic hydrogen to the (urfa of the growing film seems to be enough to overcome the thickness denendence and yows films to be produced which has higher $\sigma_{\mathrm{ph}}$ and the same $\sigma_{\mathrm{d}}$ as fere films on substrates. The very different character of the amorphous to microcryst ta ne tr ssition in RF (abrupt) and HW (gradual) observed in films deponten on sub [6] is confirmed here for films deposited on PET. The values of hyar en tilution at which the amorphous to microcrystalline transition occurs in RF for $\mathrm{T}_{\text {sub }}>5^{\circ} \mathrm{C}$ and $\mathrm{T}_{\text {sub }}=100^{\circ} \mathrm{C}$ is the same for films deposited on PET and on substrate.

\section{Conclusions}

Amorphous and microcrystalline silicon films were deposited at $100^{\circ} \mathrm{C}$ and $25^{\circ} \mathrm{C}$ on PET with electronic and structural properties comparable to those of corresponding reference films grown on substrate using the same deposition conditions.

At low temperatures $\left(\mathrm{T}_{\mathrm{sub}} \leq 100^{\circ} \mathrm{C}\right)$, the photosensitivity $\left(\sigma_{\mathrm{ph}} / \sigma_{\mathrm{d}}\right)$ of amorphous films deposited by HW is highly dependent on the film thickness. An increase of 1-2 orders of the photosensitivity is observed when the thickness is increased from $100 \mathrm{~nm}$ to $300 \mathrm{~nm}$.

For low temperature $\left(<100^{\circ} \mathrm{C}\right)$ deposition on PET, RF-PECVD is preferable for amorphous films, but HW-CVD shows more promise in the deposition of microcrystalline silicon. 


\section{References}

[1] R.E.I Schropp, B Stannowski, J.K Rath, Journal of Non-Crystalline Solids, 299 (2002) 1304-1310.

[2] H. Meiling, J. Bezemer, R.E.I Schropp, W.F. van derWeg, Mater. Res. Soc. Symp, Proc. 625-631 (2010).

[3] H. Meiling, A.M Brockhoff, J.K Rath, R.E.I Schropp, Journal of Non-Crystalline Solids, 219-225 (2008) 1135-1141.

[4] B. Stannowski, R.E.I. Schropp, R.B. Wehrspohn, M.J. Powell, ibid., 299 (2002) 1340-1344.

[5] B Stannowski, R.E.I. Schropp, Thin Solid Films 383 (1) (2001) 125-128.

[6] V.S. Waman, A.M. Funde, M.M. Kamble, M.R. Pramod, R.R. Hawaldar, D.P. Amalnerkar, V. G. Sathe, S. W. Gosavi, S. R. Jadkar, Journal of Nano, hnology, Article ID 242398, 2011.

[7] X-T Hao, J. Ma, D.H. Zhang, Y.G. Yang, H.L. Ma, C.F. Yeng, X.D. Liu, Materials Science and Engineering, 90 (2002) 50-54.

[8] M.N. Van den Donker, A. Gordijn, H. Stiebig, F. Fing B Rech, solar energy materials and solar cells 91 (7) (2007) 572-580.

[9] H. Takiguchi, A.Matoba, K.Sasaki, Y.Okamo H.Miyaza and J.Morimoto, Materials Transactions, 61 No4 (2011) 378 - 38

[10] S. Veprek, F.A. Sarott and Z. Iqbal, US Pat 117,871,94 2911.

[11]I. Ferreira, A. Cabrita, F. Braz Fernan les, E. Fortunzo, R. Martins, Materials Science and Engineering, 31, (2009)138 142.

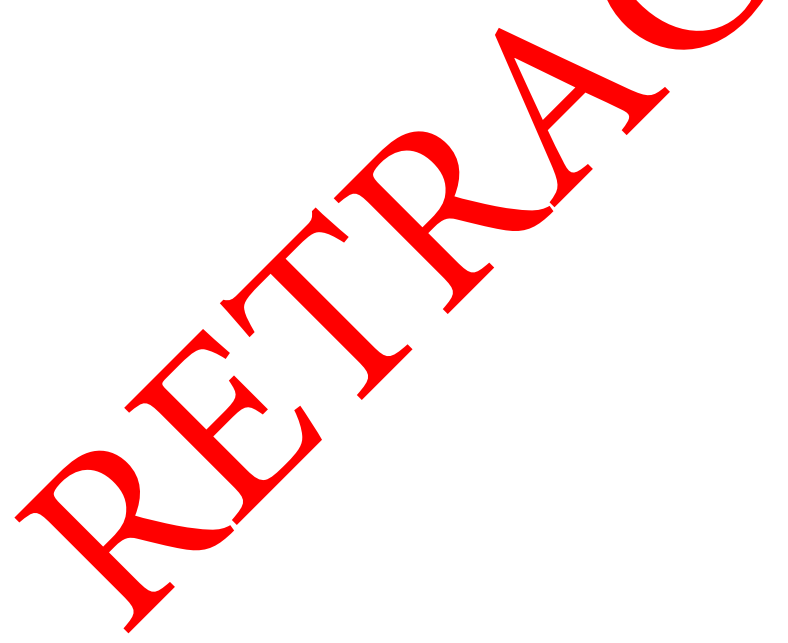

